\title{
GRM4 wt Allele
}

National Cancer Institute

\section{Source}

National Cancer Institute. GRM4 wt Allele. NCI Thesaurus. Code C114533.

Human GRM4 wild-type allele is located in the vicinity of $6 \mathrm{p} 21.3$ and is approximately 134

$\mathrm{kb}$ in length. This allele, which encodes metabotropic glutamate receptor 4 protein, is involved in lig and-dependent signal transduction. 